\title{
Spirituality and Organizations: A Proposal for a New Company Style Based on a Systematic Review of Literature ${ }^{\dagger}$
}

\author{
Carolina Vila Porras ${ }^{1, *}$ and Iván-Darío Toro-Jaramillo ${ }^{2, *}$ \\ 1 Facultad de Teología, Pontificia Universidad Javeriana, Bogotá 110231, Colombia \\ 2 Facultad de Teología, Universidad Pontificia Bolivariana, Medellín 050031, Colombia \\ * Correspondence: carolinavilap@javeriana.edu.co (C.V.P.); ivandario.toro@upb.edu.co (I.-D.T.-J.) \\ + Review article, investigation result: Ethical-spiritual itinerary for organizations, from a hermeneutic \\ correlation of the Matthean beatitudes, set down in the Theology, Religion and Culture Research Group, in \\ the Humanism and Organizations research line Medellín: Universidad Pontificia Bolivariana, ACADEMIA \\ Research Group, in the Theology of Human Action research line Bogotá: Pontificia Universidad Javeriana.
}

Received: 12 March 2020; Accepted: 10 April 2020; Published: 11 April 2020

\begin{abstract}
The purpose of this research is to propose a new company style based on a systematic review of literature, taking the Matthean beatitudes as a reference in relation to the actual needs of organizations. To such end, we searched for scientific articles in Scopus, Web of Science, EBSCO, and ATLA databases. A considerable number of investigations were found on spirituality in organizations, but none specifically covered the biblical area. This study aims to suggest ways through which the human being can be at the center of organizations for a new style of business to emerge.
\end{abstract}

Keywords: systematic review of literature; Matthean spirituality; organizations; style; the human

\section{Introduction}

This research has been conducted in the context of spirituality in organizations (Sandelands 2017; Moya 2014; Melé and Fontrodona 2017), supported by the discourse of the Matthean beatitudes, as a way of approaching this context. According to the systematic review of literature (SRL) related to leadership in companies (Mabey et al. 2017; Wahid and Mustamil 2017), humans are considered resources rather than as the central focus of organizations (Acevedo 2012; Grassl and Habisch 2011; Pirson and Lawrence 2010). Further, there are themes related to the business ethics approach with no explicit articulation of Christian ethics: the alienation of the human being in the workplace (Kumpikaitè-Valiūnienèa 2014); individualism (Aguirre Alemán et al. 2011); the inability to create an organizational climate based on the quality of interpersonal relationships (Diaz Pincheira and Garcés 2018), in addition to other problems related to ethics, such as corruption (Gómez Patiño 2014).

However, in the SRL of significant impact journals, there were no approaches related to biblical theology, in particular, with reference to the current status of research on Matthean beatitudes and organizations, which help to understand the human being as the center of organizations and thus foster a new company style. Therefore, taking into account the exponential growth of scientific research, it is necessary to provide an overview of publications that help identify gaps in literature related to the topic of research and to identify future lines of investigation.

The reason for conducting this research is largely due to the fact that professionals in the area of administration have been trained to a larger extent to find solutions to problems for the company, but they lack humanistic training. This has resulted in the current organizational model, where the 
human being is not the focus of business management, in line with functionalist stances (Toro-Jaramillo and Ramírez Ríos 2017).

The objective of this paper is to argue for the need for a new business style based on the analysis of the content of research papers and identifying themes, the most prominent authors and high impact articles, the countries with top research productivity, and the methodological contributions of these works. We searched scientific databases for articles in which we identified publications addressing problems related to the search equations used.

This research is in line with other works that manage to construct research problems and raise important concerns for companies based on the analysis of the most relevant scientific works related to organizations and spirituality (Poole 2009; Karakas 2010).

This paper has been organized as follows. After the introduction, the methodology used in the research has been discussed, including the SRL, the articles finally used for the study, and the subject analysis. Next, a theoretical framework for the analysis of the research that was identified after the SRL is presented. Finally, the results obtained from the investigation are revealed and the conclusions are presented, including SRL contributions in relation to spirituality and religion in organizations following the approaches of biblical theology in the discourse of the Matthean beatitudes, as a subcategory, to understand the human being as the center of organizations and thus propose a new company style ${ }^{1}$.

\section{Methodology}

A major difficulty with regard to literature reviews is usually the criteria for selecting articles; in recent studies, several objective criteria have been set, such as including articles published in journals with the most significant impact factors, according to Journal Citation Reports (JCRs) (Alvarez and Urbano 2011).

Based on this criterion, the articles published in journals with the highest impact factors were chosen through three steps in the present study. First was the selection of keywords to define the search equations; these were defined from the beginning to reduce bias in the SRL. The following keywords were chosen to carry out the investigation in relation to spirituality in organizations: organizations, humanism, business, work, religion, and spirituality. These keywords yielded four search equations: "organizations and spirituality", "business and religion", "spirituality and work", and "humanism and business" from the Scopus, Web of Science, EBSCO, and ATLA databases. We thus identified the journals that met the aforementioned criteria, such as the Journal of Business Ethics; Journal of Management, Spirituality, and Religion; Journal of Beliefs and Values; Asia Pacific Journal of Management; International Journal of Contemporary Hospitality Management; European Management Journal; Psychology of Religion and Spirituality; and Leadership Quarterly.

From this search, we verified that there were no articles that directly focused on beatitudes and organizations from exegetical or biblical hermeneutics perspectives, although we found various kinds of spiritual proposals within the content and development of these papers that at least showed the importance and influence that individual and community experiences of spirituality have on working life.

We found that in most of the studies of interest, the topic of spirituality appeared in the title of the work. Thus, the second step was to refine information based on the title of the documents that referred to "spirituality" and "work" or some similar terminology. We also refined the search by considering only articles, thus reducing the list of documents for reviewing publications.

The third step was to maintain consistency in the search from a strategic perspective. Therefore, in order to find the main articles about spirituality at work, we consulted articles published in specific

1 If you wish to go deeper into the word "style", in the theological sense, you may consult the following article: (Jiménez Rodríguez 2020). 
high impact scientific journals. This last filter yielded 42 studies, which were taken as an important part of the final review.

Another criterion followed in the SRL was adding some articles found in publications with a lower index but that were relevant to the research because they were studies concerning organizations and spirituality. As a consequence, 10 additional pertinent articles were chosen from the EBSCO and ATLA databases.

After the selection process, we performed an exploratory study on the research articles based on content analysis. We identified the research questions and objectives and the different methodologies used in the works. Furthermore, as part of the content analysis, we identified high impact articles and top-cited authors, the countries with the largest number of publications, and the methodological contributions made by the studies (García Peñalvo 2017, p. 1) because they provided information on the importance and strength of the subject under investigation.

Content analysis, a technique that consists mainly of the study of ideas in relation to concepts rather than the words expressed, allows for the examination of the text in the context of "sender-receiver" relations (Aigeneren 2008, p.1). This technique was used in the present study to organize the content of the articles. To such end, different categories were created, based on Berelson's work (1984): homogeneous, exhaustive (i.e., must cover the entire text), exclusive (i.e., the same content element cannot be randomly classified into other categories), objective (i.e., two different encoders must reach the same results), and appropriate or relevant (i.e., adapted to the content and purpose). The following categories were used to organize and process the data collected: spirituality, ethics, religion, and humanism in relation to organizations, companies, and businesses. Once the categories were created, we selected and arranged the information into sentences and paragraphs. Therefore, the unit of analysis was the group of words related to spirituality and organizations. Subsequently, we compared the contents grouped in each category and inferred those most relevant to the study.

Moreover, the SRL technique aided in clearly stating the research problem. This was achieved, first, through the identification and analysis of categories previously explained in content analysis. Second, we drafted a plan to justify the steps of the research and research method. Third, we collected information that was considered pertinent and sufficient to answer the problem question. Fourth, these data were studied and interpreted according to the abovementioned theoretical and methodological criteria. In other words, we considered every element that contributed to developing the research problem. We then presented our conclusions in the final report (Aigeneren 2008). Finally, we performed a correspondence analysis to describe the relations between two categories or concepts: Matthean beatitudes and organizations.

\section{Theoretical Framework}

The theoretical support underpinning the research problem focuses on organizations and spirituality and on the biblical aspect, referring to Matthean beatitudes, as a subcategory of analysis. First, we examined organizations and spirituality, seeking to visualize the void in the area and the importance of this study. Subsequently, when approaching the biblical theological field from the pericope of Matt 5:3-10, the aim was to arrive at a corresponding analysis between Matthean beatitudes and organizations and spirituality, so that it would be possible to suggest a proposal for a new company style that leads to future lines of research toward ethical-spiritual proposals.

Studies on organizations date back to the thirteenth century, with noteworthy developments in the four following centuries and, particularly, in the last century (Melé and Fontrodona 2017). So far, such studies (Mabey et al. 2017; Sandelands 2017; Acevedo 2012) have linked organizations and workplaces to spirituality (Roof 2015; Lychnell 2017; Sandelands 2017), in general, to Christian ethics and social responsibility (Melé and Fontrodona 2017; Chatterji 2017); to leadership and spirituality (Rothausen 2017); to sustainability and productivity; and to the organizational culture achieved from individual spiritual life (Brophy 2015), subsequently linked to the community (Castrillón Velásquez 2011). Organizations, for the most part, have considered human beings as 
a resource that responds more to the operational aspects of companies and to efficient positions (Toro-Jaramillo and Ramírez Ríos 2017).

Various strategies and spiritual proposals have been used in the business field that contribute to human development and its position in the organizational field (Weinberg and Locander 2014; Roof 2015; Benefiel et al. 2014; Ayoun et al. 2015; Corner 2009; Poole 2009; Gotsis and Kortezi 2008; Groen 2008; Kumpikaitè-Valiūnienėa 2014; Karakas et al. 2017), seeking not only personal well-being, but also greater corporate sustainability and productivity (Toro-Jaramillo and Ramírez Ríos 2017), which is achieved from individual (Kolodinsky et al. 2008; Roof 2015; Brophy 2015) and community (Castrillón Velásquez 2011) spiritual life.

The organizations that implement such spiritual proposals (Ayoun et al. 2015) forged a more positive organizational climate, characterized by institutional dynamics that enhance the human spirit and, therefore, boost employees' work performance (Yazdani and Murad 2015, pp. 399-417). Thus, it has been possible to respond to some realities present in companies regarding certain leadership and human-related difficulties considered to be a means of organization rather than an end in itself.

Implementing business ethics that are not explicitly articulated with Christian ethics can lead to the alienation of the human being in the workplace and can promote individualistic positions and the inability to create an organizational climate based on quality interpersonal relationships, among other aspects.

Administrative professionals have been trained to solve problems faced by companies, but they lack humanistic training. This has resulted in the current business model, in which the human being is not the central core of organizations.

Several investigations have been carried out in this corporate field (Allen and Williams 2017; Karakas et al. 2017; Wahid and Mustamil 2017; Ananthram and Chan 2016; Roof 2015; Brophy 2015; Ayoun et al. 2015; Benefiel et al. 2014; Weinberg and Locander 2014; Karakas 2010; Tourish and Tourish 2010; Lynn et al. 2009; Corner 2009; Poole 2009; Kolodinsky et al. 2008; Groen 2008; Kumpikaitè-Valiūnienėa 2014), which have employed different spiritual strategies and proposals, favoring human development in the business field (Weinberg and Locander 2014; Roof 2015; Benefiel et al. 2014; Ayoun et al. 2015; Corner 2009; Poole 2009; Gotsis and Kortezi 2008; Groen 2008; Kumpikaitè-Valiūnienėa 2014; Karakas et al. 2017). They have sought not only human well-being, but also a more sustainable and productive organizational culture, achieved from individual spiritual life (Kolodinsky et al. 2008; Roof 2015; Brophy 2015), subsequently manifesting in the community (Castrillón Velásquez 2011).

Along with the execution of these spiritual proposals, a more authentic organizational climate has also been achieved in some cases, where institutional policies are directed toward strengthening people's spiritual lives and, consequently, their work performance (Yazdani and Murad 2015).

A biblical SRL at this level was necessary to show the innovative aspects of this study and to justify and support the aforementioned problem. To such end, we also considered the work entitled "Ser cristiano hoy: propuesta humanizadora en Mt 5, 3-10" ("Ser Cristiano hoy: propuesta humanizadora en Mt 5, 3-10," Vila Porras 2016, pp. 1-148), where a biblical exegesis of the Matthean beatitudes text was performed.

In this regard, and with the purpose of clarifying the proposed new business style, it is necessary to understand the meanings of the beatitudes text, the first of the five programmatic speeches said by Jesus that constitutes the principle of all his teaching (Acosta 2003). For its part, the base term of Matt 5:3-10 is makarios, which translates as blessed, blissful, or happy. "Makarizo" means proclaiming someone as blessed, calling someone happy, or congratulating someone. In this way, "makarismos" is translated as bliss, praise, and congratulation (Becker 1990).

Moreover, this pericope is related to texts from the Old Testament that express their macarisms with pericopes related to Matt 5:3-10, as well as with the whole of the Gospel of Matthew, in which the guiding principle is the inauguration of the Kingdom of Heaven, a central theme of this gospel. 
It is important to point out also that the Second Testament macarism is not directly derived from the Jewish Old Testament or the Greek-Hellenistic environment (Strecker 1998). The content is influenced by certain wisdom, ethical, and apocalyptic elements, but its special feature lies in the encounter with the Christ event (Strecker 1998). This relationship was established in Jesus' preaching and was subsequently developed by the prophets of early Christianity and New Testament writers (Strecker 1998). In Matthew, the macarisms are conditions that are attached to be admitted into the Kingdom of Heaven and have a paracletic orientation (Levoratti 2003).

Here lies the importance of showing the contributions of biblical hermeneutics (Andiñach 2012) from the Matthean beatitudes to achieve a corresponding relationship between the context of the organizations and the Matthean text. The global understanding of the biblical text expands, and business reality is better understood such that an ethical-spiritual itinerary may be proposed from a hermeneutic consistent with business reality, thus achieving a new style of organization.

Matthean beatitudes highlight the human because this pericope includes a person's relationship with himself, with the world, and with the other. Life experience in the light of the beatitudes allows us to build a path in which horizontal and vertical relationships are taken into account to build a more human world that is in line with the divine project. An example of these horizontal and vertical relationships is the beatitudes (vv. 4-6), which show the attitude that the followers of Jesus assume toward God, and the next three beatitudes (vv. 7-9), which deal with Jesus' disciples' attitude toward their brothers (Vila Porras 2016).

Therefore, in an organizational context where the human being is considered to be a resource that responds to functional structures, the evangelical discourse focused on the human and its relationship with the transcendental acquires meaning and gains momentum.

Consequently, the human position in the organizational field should be rethought, with a view to positioning people at the core of business performance, while at the same time allowing the human being to rediscover and rethink another style of being in the workplace.

\section{Results}

This study allowed, through SRL and content analysis, to find the gap, namely, the Matthean beatitudes that have not yet been used as a way of understanding the field of spirituality and religion in the world of organizations. Subsequently, the research allowed us to arrive at an understanding of the meaning of the selected articles and texts, and thus to construct the research problem.

In total, 52 articles were found in the Scopus, Web of Science, EBSCO, and ATLA databases that attach importance to the research subject and a significant number of articles and authors addressing the issue of spirituality and organizations from different perspectives (Table 1). In Q1 journals, 28 articles were found; in Q2, 3 articles were identified; in Q3, 8 studies were found; and in Q4, there were 3 investigations, adding up to a total of 42 articles. The remaining 10 to complete the initial number were extracted from the EBSCO and ATLA databases.

After choosing and debugging texts, an exploratory study was carried out as a first approach to the research papers, classifying them according to the contribution made to research in relation to the research problem and its methodology.

The main contributions offered by these studies to the proposal of a new company style should be listed. First, the figure of Jesus of Nazareth constitutes a viable model for ethically guiding business leadership because through him, human beings will be considered central to business practice (Sandelands 2017, pp. 771-80; Mabey et al. 2017; Ayoun et al. 2015). Personalism and other philosophical approaches enrich the business ethic proposal and owner behaviors, which allow us to think about the place occupied by employees in an organization (Acevedo 2012, pp. 197-279; Kininmonth 2016, pp. 1236-61; Gotsis and Kortezi 2008, pp. 575-600). From the encyclical Caritas in Veritate of Pope Benedict XVI, there are studies that propose to move forward toward a new conceptualization of the weak relation between economics and ethics, an issue that necessitates contextualization and understanding of business ethics (Grassl and Habisch 2011, pp. 37-49). 
From the arts standpoint, the possibility of promoting human dignity in organizational life is put forth (Pless et al. 2017, pp. 535-46). Another outstanding contribution in these findings is a part of Darwin's theory, renewed and labeled as "humanist" to make distinctions between current "economic" conceptions (Pirson and Lawrence 2010, pp. 553-65).

Other research is related to applying a meditative empirical exercise from Christianity, Islam, and Eastern traditions to small businesses. This is aimed at personal growth, increasing one's ability to address each situation in a different light and influencing employee practices, which allows us to understand the direct influence exerted by different beliefs on business performance (Lychnell 2017, pp. 255-75; Hendar et al. 2017, pp. 78-102; Groen 2008, pp. 193-204; Van Buren and Greenwood 2013, pp. 707-19). Another contribution that stands out relates to the alienation of human beings from work, a concern that is being studied in relation to organizations and spirituality to envision a different scenario for humans (Kumpikaitè-Valiūnienèa 2014, pp. 1205-12). Finally, there are articles that show the positive influence that an experience of spirituality has in the workplace, contributing to this research by helping to understand how an experience of spirituality at work enriches employees' work life and personal life (Kolodinsky et al. 2008; Vasconcelos 2009, pp. 930-49; Lynn et al. 2009).

It should be noted that although the remaining 32 articles that do not appear in Table 2 do not point directly to the research proposal, they are part of the field of study (i.e., spirituality and organizations) and are also of interest to the present study by indicating the need for the possibility of a new business style; for example, in dialog between biblical and business ethics.

The topics addressed by this group of articles refer to different subjects: Corporate social responsibility, which relates to the country's culture and ethics, such that social structure depends on religious values and the occupational system (Chatterji 2017); the study of social enterprise in the theologies of William Temple and John Milbank-both theologies are compared and discussed with regards to whether they support demanding social enterprises (Krinks 2016); the importance of religion in employee practices for obtaining the social license to operate (Cui et al. 2016); and the explanation of the relations between time management and growth, maturation and nutrition of one's spirituality, and religious practice both at home and at work (Jensen and Neck 2017).

Other pieces of research contribute elements to the suggested proposal when dealing, for example, with conflicts and solutions in companies that espouse some religious beliefs (Moya 2014); these are studies that seek to identify problems, challenges, and techniques in business intelligence (Wani and Jabin 2018); works that focus on humanism, economic sciences, and business and then give an account of humanist perspectives, as developed by Catholic social teachings, with particular focus on an existential intellectual framework, where the measure of justice is love, the principle of personal actions, and social order (Melé and Martin 2016).

Other studies provide ideas such as building a community first and a company second (Castrillón Velásquez 2011), taking into consideration the current situation of Christian ethics and spirituality in business (Melé and Fontrodona 2017) and showing how integrating leadership development with Ignatian spirituality leads to a model for designing a spiritual leader development practice (Rothausen 2017). In addition, the discussion enriches the theoretical contribution made to literature on business ethics through a phenomenology of virtues that provide a unique vision of various forms of moral imagination (Karakas et al. 2017).

Another study presents a synthesis of two interviews and describes the professional life of Andre Delbecq, in which a study of the spirituality of executive leaders is emphasized (Allen and Williams 2017). Research also focuses on issues such as proving that organizations can still develop a business model that adopts and adapts to spiritual, ethical, and moral leadership styles to guarantee employees' well-being, organizational sustainability, and social responsibility (Wahid and Mustamil 2017). The points raised by some authors in relation to the theory of virtue ethics that help examine the types of virtues that are proclaimed by religion and spirituality when forming ethical behavior are also interesting (Ananthram and Chan 2016). 
Table 1. Classification of the articles found in the databases.

\begin{tabular}{|c|c|c|c|}
\hline DATA BASE & ARTICLE & AUTHOR(S) & QUARTILETIL \\
\hline SCOPUS & $\begin{array}{l}\text { Having Burned the Straw Man of Christian Spiritual Leadership, What can we Learn from Jesus } \\
\text { AboutLeading Life Ethically? }\end{array}$ & $\begin{array}{l}\text { Christopher Mabey; MervynConroy; Karen Blakeley; Sara } \\
\text { de Marco, 2017. }\end{array}$ & Q1 \\
\hline SCOPUS & The Real Mystery of Positive Business: A Response from Christian Faith & Sandelands, Lloyd. E., 2017. & Q1 \\
\hline SCOPUS & Personalist Business Ethics and HumanisticManagement: Insights from Jacques Maritain & Acevedo, A., 2012. & Q1 \\
\hline SCOPUS & Ethics and economics: Towards a new humanistic synthesis for business & Grassl, W. (a); Habisch, A. (b), 2011. & Q1 \\
\hline SCOPUS & Humanism in business - Towards a paradigm shift? & Pirson, M.A.(A); Lawrence, P.R. (B), 2010. & Q1 \\
\hline SCOPUS & Art, Ethics, and the Promotion of Human Dignity & Pless, N.M.; Maak, T.; Harris, H., 2017. & $\mathrm{Q} 1$ \\
\hline SCOPUS & When work becomes meditation: How managers use work as a tool for personal growth & Lychnell, L., 2017. & Q1 \\
\hline SCOPUS & Weber's Protestant Work Ethic: a case study of Scottish entrepreneurs, the Coats Family of Paisley & Kininmonth, K., 2016. & Q1 \\
\hline SCOPUS & $\begin{array}{l}\text { Social enterprise in the theologies of } \\
\text { William Temple and John Milbank }\end{array}$ & Krinks, P., 2016. & Q1 \\
\hline SCOPUS & Community Religion, Employees, and the Social License to Operate & Cui, J., Jo, H., Velasquez, M.G., 2016. & Q1 \\
\hline SCOPUS & $\begin{array}{l}\text { The relation of religion and spirituality to Time management: examining the lives and careers of } \\
\text { Franklin Covey co-founders-Hyrum W. Smith and Stephen R. Covey }\end{array}$ & Jensen, J.R., Neck, C.P., 2017. & Q1 \\
\hline WEB OF SCIENCE & Christian Ethics and Spirituality in Leading Business Organizations: Editorial Introduction & Melé, Domenèc; Fontrodona, Joan, 2017. & Q1 \\
\hline WEB OF SCIENCE & $\begin{array}{l}\text { Having Burned the Straw Man of Christian Spiritual Leadership, what can We Learn from Jesus } \\
\text { About Leading Ethically? }\end{array}$ & $\begin{array}{l}\text { Mabey; Christopher Conroy; Mervyn; Blakeley, Karen; et al, } \\
2017 .\end{array}$ & Q1 \\
\hline WEB OF SCIENCE & $\begin{array}{l}\text { Integrating Leadership Development with Ignatian Spirituality: A Model for Designing a } \\
\text { Spiritual Leader Development Practice }\end{array}$ & Rothausen, Teresa J., 2017. & Q1 \\
\hline WEB OF SCIENCE & $\begin{array}{l}\text { Exploring the Diversity of Virtues Through the Lens of Moral Imagination: A Qualitative Inquiry } \\
\text { into Organizational Virtues in the Turkish Context }\end{array}$ & Karakas, Fahri; Sarigollu, Emine; Uygur, Selcuk, 2017. & Q1 \\
\hline WEB OF SCIENCE & Spirituality Incorporated: Including Convergent Spiritual Values in Business & Brophy, Matthew, 2015. & Q1 \\
\hline WEB OF SCIENCE & The Association of Individual Spirituality on Employee Engagement: The Spirit at Work & Roof, Richard A., 2015. & Q1 \\
\hline WEB OF SCIENCE & Is workplace spirituality associated with business ethics? & Ayoun, Baker; Rowe, Louis; Yassine, Fatima, 2015. & Q1 \\
\hline WEB OF SCIENCE & Advancing workplace spiritual development: A dyadic mentoring approach & Weinberg, Frankie J.; Locander, William B., 2014. & Q1 \\
\hline WEB OF SCIENCE & The Genesis of Employment Ethics & Van Buren, Harry J., III; Greenwood, Michelle, 2103. & Q1 \\
\hline WEB OF SCIENCE & Personalist Business Ethics and Humanistic Management: Insights from Jacques Maritain & Acevedo, Alma, 2012. & Q1 \\
\hline WEB OF SCIENCE & Spirituality and Performance in Organizations: A Literature Review & Karakas, Fahri, 2010. & Q1 \\
\hline WEB OF SCIENCE & Spiritual Climate of Business Organizations and Its Impact on Customers' Experience & Pandey, Ashish; Gupta, Rajen K.; Arora, A. P., 2009. & Q1 \\
\hline WEB OF SCIENCE & $\begin{array}{l}\text { Faith at Work Scale (FWS): Justification, Development, and Validation of a Measure of } \\
\text { Judeo-Christian Religion in the Workplace }\end{array}$ & $\begin{array}{l}\text { Lynn, Monty L.; Naughton, Michael J.; Vander Veen, Steve, } \\
2009 .\end{array}$ & Q1 \\
\hline WEB OF SCIENCE & Workplace Spirituality and Business Ethics: Insights from an Eastern Spiritual Tradition & Corner, Patricia Doyle, 2009. & Q1 \\
\hline WEB OF SCIENCE & Organizational Spirituality-A Literature Review & Poole, Eve, 2009. & Q1 \\
\hline
\end{tabular}


Table 1. Cont.

\begin{tabular}{|c|c|c|c|}
\hline DATA BASE & ARTICLE & AUTHOR(S) & QUARTILETIL \\
\hline WEB OF SCIENCE & $\begin{array}{l}\text { Workplace values and outcomes: Exploring personal, organizational, and interactive workplace } \\
\text { spirituality }\end{array}$ & $\begin{array}{l}\text { Kolodinsky, Robert W.; Giacalone, Robert A.; Jurkiewicz, } \\
\text { Carole L., 2008. }\end{array}$ & Q1 \\
\hline WEB OF SCIENCE & Philosophical foundations of workplace spirituality: A critical approach & Gotsis, George; Kortezi, Zoi, 2008. & Q1 \\
\hline WEB OF SCIENCE & $\begin{array}{l}\begin{array}{l}\text { Religiosity, spirituality and ethical decision-making: Perspectives from executives in Indian } \\
\text { multinational enterprises }\end{array} \\
\end{array}$ & Ananthram, Subramaniam; Chan, Christopher, 2016. & Q2 \\
\hline WEB OF SCIENCE & Building an integral metatheory of management & Antonio Robledo, Marco, 2014. & Q2 \\
\hline WEB OF SCIENCE & Spirituality and Religion in the Workplace: History, Theory, and Research & Benefiel, Margaret; Fry, W.; Geigle, David, 2014. Louis & Q2 \\
\hline SCOPUS & Introducing the religion-centric positional advantage to Indonesian small businesses & Hendar, H., Ferdinand, A.T., Nurhayati, T., 2017. & Q3 \\
\hline SCOPUS & $\begin{array}{c}\text { La religión en la empresa: problemas y soluciones [Religion in companies: Conflicts and } \\
\text { solutions] }\end{array}$ & Moya, A.R., 2014. & Q3 \\
\hline WEB OF SCIENCE & Navigating the Study of Executive Leaders' Spirituality: Andre Delbecq's Journey & Allen, Stuart; Williams, Peter, 2017. & Q3 \\
\hline WEB OF SCIENCE & $\begin{array}{l}\text { Links between the Spiritual Intelligence of the Leader and an Organization's Service Quality: A } \\
\text { Theoretical Approach }\end{array}$ & Silingiene, Violeta; Skeriene, Sandrita, 2016. & Q3 \\
\hline WEB OF SCIENCE & $\begin{array}{l}\text { Spirituality at Work and its Implications for Leadership and Followership: A Post-structuralist } \\
\text { Perspective }\end{array}$ & Tourish, Dennis; Tourish, Naheed, 2010. & Q3 \\
\hline WEB OF SCIENCE & Theorizing the Dark Side of the Workplace Spirituality Movement & $\begin{array}{l}\text { Lips-Wiersma, Marjolein; Dean, Kathy Lund; Fornaciari, } \\
\text { Charles J., } 2009 .\end{array}$ & Q3 \\
\hline WEB OF SCIENCE & Intuition, Prayer, and Managerial Decision-making Processes: A Religion-Based Framework & Vasconcelos, Anselmo Ferreira, 2009. & Q3 \\
\hline SCOPUS & $\begin{array}{l}\text { Justicia y reino de los cielos: análisis literario de las bienaventuranzas de Mateo [Justice and } \\
\text { Heaven: Literary Analysis of Mathew's beatitudes] }\end{array}$ & Acosta, Ricardo, 2003. & Q3 \\
\hline SCOPUS & A note on corporate social responsibility & Chatterji, M., 2017. & Q4 \\
\hline WEB OF SCIENCE & $\begin{array}{l}\text { Ways to maximize the triple bottom line of the telecommunication industry in Malaysia The } \\
\text { potentials of spiritual well-being through spiritual leadership }\end{array}$ & $\begin{array}{l}\text { Wahid, Nur Kamariah Abdul; Mustamil, Norizah Mohd, } \\
\qquad 2017 .\end{array}$ & Q4 \\
\hline WEB OF SCIENCE & Workplace spirituality and organizational commitment: An empirical study & Groen, Janet, 2008. & Q4 \\
\hline EBSCO & Humanism in Economics and Business. Perspectives of the Catholic Social Tradition & Melé, Domenèc and Schlag, Martin, 2016. & \\
\hline EBSCO & Humanism in business. & M. Pirson, En Amann, S. Khan, and E. Kimakowitz, 2010. & \\
\hline EBSCO & Del líder al humano en la organización [From the leader to the human in organization] & David Alonso Castrillón Velasquez, 2011. & \\
\hline EBSCO & $\begin{array}{l}\text { El intercambio en las organizaciones. Reflexiones en torno a las Organizaciones de la Sociedad } \\
\text { Civil [Exchange in organizations: Environmental reflections. Organizations in civilian society] }\end{array}$ & Diana del Consuelo Caldera González, 2007. & \\
\hline EBSCO & A community first. & Priest, Steve, 2010. & \\
\hline EBSCO & A humanistic perspective of firm competitive behavior. & Offstein, Evan H.; Gnyawali, Devi R., 2006. & \\
\hline
\end{tabular}


Table 1. Cont.

\begin{tabular}{cccc}
\hline DATA BASE & ARTICLE & QUTHOR(S) \\
\hline ATLA & “Hidden in plain sight”: the significance of religion and spirituality in secular organizations & Cadge, Wendy; Konieczny, Mary Ellen, 2014. \\
ATLA & The relationship between workplace spirituality and innovative work behavior: The mediating \\
role of perceived person-organization fit & Afsar, Bilal; Rehman, Maryam, 2015. & S Lee, KJ Lovelace, CC Manz, 2014. \\
\hline ATLA & Serving with spirit: an integrative model of workplace spirituality within service organizations & 52 \\
\hline TOTAL & Source: Own elaboration from Scopus, Web of Science, EBSCO, and ATLA databases.
\end{tabular}


Table 2. Research topics.

\begin{tabular}{|c|c|}
\hline Research Contribution & Article Total \\
\hline $\begin{array}{c}\text { Positive influence of experiencing } \\
\text { spirituality at work }\end{array}$ & 5 \\
\hline $\begin{array}{c}\text { Applying an empirical meditative exercise to small } \\
\text { companies from different religions including } \\
\text { Christianity, Islam, and Eastern traditions that } \\
\text { promotes personal growth and broadens skills } \\
\text { of approaching each situation in } \\
\text { a different light, thus influencing employee } \\
\text { practices }\end{array}$ & 4 \\
\hline $\begin{array}{l}\text { The figure of Jesus of Nazareth constitutes a viable } \\
\text { role model providing ethical guidance to business } \\
\text { leadership }\end{array}$ & 3 \\
\hline $\begin{array}{c}\text { Personalism and other approaches as solid } \\
\text { philosophical bases for business ethics and } \\
\text { business owner behaviors }\end{array}$ & 3 \\
\hline $\begin{array}{c}\text { Through the arts, human dignity can be promoted } \\
\text { in organizational life }\end{array}$ & 2 \\
\hline Alienation of the human being in the workplace & 1 \\
\hline $\begin{array}{l}\text { As from the encyclical Caritas in Veritate of Pope } \\
\text { Benedict XVI, the progress toward a new } \\
\text { conceptualization of the weak relationship between } \\
\text { the economy } \\
\text { and ethics has been studied }\end{array}$ & 1 \\
\hline $\begin{array}{l}\text { Darwin's theory renewed and labeled as } \\
\text { "humanist" to draw distinctions between } \\
\text { current "economic" conceptions }\end{array}$ & 1 \\
\hline
\end{tabular}

There are almost no empirical studies, so the results achieved from empirical work seeking to analyze the relations between individual spirituality and general employee commitment are of interest to the research (Roof 2015). Some studies show the importance of including spiritual values in a company, to the extent that they are shared by the company directors (Brophy 2015), along with those who seek to answer the question "is spirituality in the workplace associated with business ethics?" (Ayoun et al. 2015). Other studies seek to build an integral metatheory of management to respond to the challenges present in organizations and societies (Robledo 2014); to establish through a theoretical approach the links between the leader's spiritual intelligence and the service quality of an organization (Silingiene and Skeriene 2016); to explore underlying assumptions and stories, as well as explore the state of current theory and empirical research regarding spirituality, religion, and work (Benefiel et al. 2014). Another useful study shows that spirituality is more beneficial when it is encouraged at an individual level than at a collective level (Weinberg and Locander 2014).

There are papers that focus on literature review, which, in addition to supporting this type of research, take note of spirituality and performance in organizations (Karakas 2010); the findings of which seek to abolish the distinction between people's work-based lives, on the one hand, and their personal lives and value systems, on the other (Tourish and Tourish 2010). Some papers theorize about the dark side of the workplace spirituality movement (Lips-Wiersma et al. 2009) and how employee spirituality is reflected in the work environment (Pandey et al. 2009).

In summary, all the issues discussed herein contribute to contextualizing the research problem and allow us to understand the influence exerted by spirituality and ethics on employees' lives and in different organizational fields, such as the work environment, sustainability, customer service, and leadership, among others. These studies help visualize a new company style, where the human being is considered an end instead of a means for economic achievements. 
From the Scopus and Web of Science databases, we identified the most cited and referenced articles and authors, along with the countries that have published the most number of papers in the area.

Tables 3 and 4 reveal the importance of the topic and the influence of research. Considerable research has been done in the field of organizations and spirituality, but there is scarce material on the possibility of a dialog between biblical and business ethics. The intention has been to discuss this issue in the present investigation by proposing a new business style, where the human being is considered to be at the center of business performance. The latter, although not clearly defined by authors, can be understood from between the lines in cited research. It is striking that this research is related to the work conducted by authors in other parts of the world and how, in the case of Colombia, because of the low number of studies and authors, this issue is still not dealt with. Therefore, the relevance of this study in Colombia is high.

Table 3. Top 10 cited authors.

\begin{tabular}{ccc}
\hline No. & Author(s) & Number of Quotes \\
\hline 1 & Karakas, Fahri & 537 \\
2 & Pina e Cunha, Miguel; Rego, Arménio & 463 \\
3 & Kolodinsky, Robert W.; Giacalone, Robert A.; & 400 \\
& Jurkiewicz, Carole L. & \\
4 & Gotsis, George; Kortezi, Zoi & 225 \\
5 & Pirson, M.A.; Lawrence, P.R. & 207 \\
7 & Benefiel, Margaret; Fry, Louis W.; Geigle, & 125 \\
8 & Lips-Wiersma, Marjolein; Dean, Kathy Lund; & 118 \\
9 & Fornaciari, Charles J & 101 \\
10 & Lynn, Monty L.; Naughton, Michael J.; & \\
& VanderVeen, Steve & 91 \\
\end{tabular}

Table 4. Top 10 most productive countries.

\begin{tabular}{ccc}
\hline No. & Country & Article \\
\hline & & TOTAL \\
2 & United States & 20 \\
3 & England & 7 \\
4 & Canada & 3 \\
5 & New Zealand & 3 \\
6 & Spain & 2 \\
7 & Lithuania & 2 \\
8 & Australia & 3 \\
9 & Portugal & 1 \\
10 & India & 1 \\
\hline
\end{tabular}

Source: Own elaboration from Scopus, Web of Science, EBSCO, and ATLA databases.

Among the methodologies and methods used in the different articles, different proposals were found. It should be noted that only 30 articles specified the method used in their research; the remaining 22 did not discuss methodology or methods throughout the article.

From Table 5, it can be inferred that empirical studies that address the research problem are missing because the studies are mostly based on theoretical approaches. Some studies have provided critical literature reviews, comparative studies, document reviews, and case studies. Furthermore, 
the 22 remaining articles that do not mention methodology or methods also make up part of the theoretical approach.

Table 5. Methodological contributions.

\begin{tabular}{ccc}
\hline No. & Methodological Contribution & Total Articles \\
\hline 1 & Theoretical focus & 11 \\
2 & Empirical studies & 7 \\
3 & Comparative studies & 3 \\
4 & Critical reviews of literature & 3 \\
5 & Content analysis & 1 \\
6 & Comparison of various techniques & 1 \\
7 & Document review & 1 \\
8 & Theory of virtue ethics & 1 \\
9 & Post-structuralist perspective & 1 \\
10 & Case study & 1 \\
& TOTAL & 30 \\
\hline
\end{tabular}

Source: Own elaboration from Scopus, Web of Science, EBSCO, and ATLA databases.

Therefore, the analysis of the findings takes into account that all the papers for the SRL were selected from the field of organizations and spirituality. It is clear from the Christian, Islamic, and Hindu religions, and those of these philosophies lived or experienced by organizational groups, that spirituality creates a positive impact on personal spiritual growth, and this is subsequently reflected in employer and employee labor outcomes. This also fosters a more favorable organizational climate, better time management, and the humanization of business practice, with the human being at the center of the organization, and results in community experience taking precedence over the company, which often comes in second place.

There are studies that demonstrate organizational failures in relation to education and training with regard to moral life, affective leaders, and relationship management, including spiritual direction. Furthermore, business models that guarantee employees' well-being, organizational sustainability, and social responsibility with no sacrifice to their profitability have been introduced. The effects of prayer in managerial decision-making have been investigated. Finally, alienation in the workplace has been one of the least directly worked on subjects.

\section{Conclusions}

This paper aims to impact the business field, which, to some degree nowadays, suffers from a lack of humanism. The aim is to position, in any human labor group, the human being as an end rather than as a means; to forge a good organizational climate; and to foster the spiritual growth of those constituting the organization. In short, a new style of business and governance is proposed, alongside the possibility of examining the ethical-spiritual itinerary in future research to conceive another field of action for the theologian in the heart of the world and organizations.

Another consequence of this study could be greater sustainability in organizations, because a company that considers its workers as fundamental components will cultivate a human group with ethical-spiritual values capable of giving their best, which will have a direct impact on business production.

Through a SRL and content analysis, a research problem corresponding to business reality was constructed such that humans help to achieve company goals. Therefore, the end of this investigation was fulfilled with the development of the research problem by positing the need to formulate a new company style, although in Colombia there are not enough studies and research regarding the subject. Furthermore, there are more empirical studies that show the reality of the issue.

We assessed the strengths and weaknesses in relation to achieving this end. As for strengths, a great wealth and variety of research has been carried out in the field of organizations and spirituality, which 
has facilitated the selection, collection, and contextualization of information. Furthermore, the research papers reviewed in this study have yielded several topics that enable their characterization and make it easier to find the gap that existed in the literature. Focusing the study on a single problem found in the organizational context and having discovered from the review the need to investigate the gap led to the aforementioned research problem aimed at promoting greater humanization in companies.

The findings of the SRL indicate that from the biblical theological field, global possibilities are endless because, at least in Colombia, there are not enough studies that correlate the biblical text, in this case the Matthean beatitudes, with organizations. Furthermore, research poses different alternatives for exploration in companies to which an interesting and innovative contribution can be made from biblical theology. The urgent need for humanization and focusing on the human in business practice, organizational culture, and employer-employee behaviors is clear. At present, it is necessary to deepen the focus on humans and for people to be taken into account not as resources but as ends in themselves, whose relevance is not in solving operational issues of organizations but as the center, the protagonist, or the most important factor in business action. For these reasons, the present study is the starting point of many research possibilities and opens up new ways of exploration in relation to the different organizational contexts mentioned throughout the article.

Author Contributions: C.V.P., principal researcher and I.-D.T.-J., director of the investigation. All authors have read and agreed to the published version of the manuscript.

Funding: CIDI 803B-06/17-14 Universidad Pontificia Bolivariana Medellín-Colombia.

Conflicts of Interest: The authors declare no conflict of interest.

\section{References}

Acevedo, Alma. 2012. Personalist Business Ethics and Humanistic Management: Insights from Jacques Maritain. Journal of Business Ethics 105: 197-279. [CrossRef]

Acosta, Richard. 2003. Justicia y Reino de los Cielos: Análisis literário de las bienaventuranzas de Mateo. Theologica Xaveriana 147: 317-48.

Aguirre Alemán, María Guadalupe, José Luis Sánchez Leyva, Javier Gómez López, and Lauro Fernández Vidal. 2011. Ética y Valores: ¿Elementos necesarios en el entorno laboral? Revista de Economía, Negocios y Finanzas 2: 1-10.

Aigeneren, Miguel. 2008. Análisis de Contenido: Una Introducción. Medellín: Centro de Estudios de Opinión, Universidad de Antioquia, pp. 1-52.

Allen, Stuart, and Peter Williams. 2017. Navigating the Study of Executive Leaders' Spirituality: Andre Delbecq's Journey. Journal of Management Inquiry 26: 216-24. [CrossRef]

Alvarez, Claudia, and David Urbano. 2011. Una década de investigación basada en el GEM: Logros y retos, Academia. Revista Latinoamericana de Administración 46: 16-37.

Ananthram, Subramaniam, and Christopher Chan. 2016. Religiosity, spirituality and ethical decision-making: Perspectives from executives in Indian multinational enterprises. Asia Pacific Journal of Management 33: 843-80. [CrossRef]

Andiñach, Pablo R. 2012. Introducción hermenéutica al Antiguo Testamento. Navarra: Verbo Divino.

Ayoun, Baker, Louis Rowe, and Fatima Yassine. 2015. Is workplace spirituality associated with business ethics? International Journal of Contemporary Hospitality Management 27: 938-57. [CrossRef]

Becker, Ulrich. 1990. Bienaventurado. In Diccionario Teológico del Nuevo Testamento. Edited by Coenen Lothar, Beyreuther Erich and Bietenhard Hans. Salamanca: Sígueme, vol. I, pp. 182-84.

Benefiel, Margaret, Louis W. Fry, and David Geigle. 2014. Spirituality and religion in the workplace: History, theory, and research. Psychology of Religion and Spirituality 6: 175-87. [CrossRef]

Berelson, Bernard. 1984. Content Analysis in Communication Researches. Glencoe: Free Press.

Brophy, Matthew. 2015. Spirituality Incorporated: Including Convergent Spiritual Values in Business. Journal of Business Ethics 132: 779-94. [CrossRef]

Castrillón Velásquez, David Alonso. 2011. Del líder humano en la organización. Pensamiento y Gestión 31: 34-55. 
Chatterji, Manas. 2017. A note on corporate social responsibility. Contributions to Conflict Management. Peace Economics and Development 26: 229-34.

Corner, Patricia Doyle. 2009. Workplace, spirituality and business ethics: Insights from an Eastern Spiritual Tradition. Journal of Business Ethics 85: 377-89. [CrossRef]

Cui, Jinhua, Hoje Jo, and Manuel G. Velasquez. 2016. Community Religion, Employees, and the Social License to Operate. Journal of Business Ethics 136: 775-807. [CrossRef]

Diaz Pincheira, Francisco Javier, and Moisés Esteban Carrasco Garcés. 2018. Efectos del clima organizacional y los riesgos psicosociales sobre la felicidad en el trabajo. Contaduría y Administración 63: 1-14. [CrossRef]

García Peñalvo, Francisco José. 2017. Revisión Sistemática de Literatura en los Trabajos de Final de Máster y Tesis Doctorales. Seminario de Marzo de 2017 en el Contexto del Programa de Doctorado de Formación en la Sociedad del Conocimiento de la Universidad de Salamanca. pp. 1-95. Available online: https: //es.slideshare.net/grialusal/slr-73184207 (accessed on 20 November 2019).

Gómez Patiño, Dilia Paola. 2014. Corrupción y colusión: Asuntos del sector empresarial en Colombia. Revista Prolegómenos: Derechos y Valores 17: 43-56. [CrossRef]

Gotsis, George, and Zoi Kortezi. 2008. Philosophical foundations of workplace spirituality: A critical approach. Journal of Business Ethics 78: 575-600. [CrossRef]

Grassl, Wolfgang, and André Habisch. 2011. Ética y Economía: Hacia una nueva síntesis humanística para los negocios. Journal of Business Ethics 99: 37-49. [CrossRef]

Groen, Janet. 2008. Workplace spirituality and organizational commitment: An empirical study. Journal of Organizational Change Management 13: 193-204.

Hendar, Hendar, Augusti Tae Ferdinand, and Tatiek Nurhayati. 2017. Introducing the religion-centric positional advantage to Indonesian small businesses. Management and Marketing 12: 78-102. [CrossRef]

Jensen, Jordan R., and Christopher P. Neck. 2017. The relation of religion and spirituality to time management: Examining the lives and careers of FranklinCovey co-founders-Hyrum W. Smith \& Stephen R. Covey. Journal of Management, Spirituality and Religion 14: 1-14.

Jiménez Rodríguez, Luis Orlando. 2020. El concepto teológico de 'estilo' como clave de lectura de Laudato si' y Gaudete et exsultate: una manera de encontrar a Dios en la acción transformadora del mundo. Theologica Xaveriana 189: 1-28. [CrossRef]

Karakas, Fahri. 2010. Spirituality and performance in organizations: A Literature review. Journal of Business Ethics 94: 89-106. [CrossRef]

Karakas, Fahri, Emine Sarigollu, and Selcuk Uygur. 2017. Exploring the diversity of virtues through the lens of moral imagination: A qualitative inquiry into organizational virtues in the Turkish Context. Journal of Business Ethics 141: 731-44. [CrossRef]

Kininmonth, Kirsten. 2016. Weber's protestant work ethic: A case study of Scottish entrepreneurs, the coats family of Paisley. Business History 58: 1236-61. [CrossRef]

Kolodinsky, Robert W., Robert A. Giacalone, and Carole L. Jurkiewicz. 2008. Workplace values and outcomes: Exploring personal, organizational, and interactive workplace spirituality. Journal of Business Ethics 81: 465-80. [CrossRef]

Krinks, Philip. 2016. Social enterprise in the theologies of William Temple and John Milbank. Journal of Beliefs and Values 37: 282-95. [CrossRef]

Kumpikaitè-Valiūnienèa, Vilmantè. 2014. Spirituality at work: Comparison analysis. $10^{\mathrm{a}}$ Conferencia Internacional de Gestión Estratégica. Procedia Social and Behavioral Sciences 150: 1205-12. [CrossRef]

Levoratti, Armando. 2003. Evangelio según san Mateo. In Comentario Bíblico Latinoamericano Nuevo Testamento. Navarra: Verbo Divino, pp. 275-398.

Lips-Wiersma, Marjolein, Kathy Lund Dean, and Charles J. Fornaciari. 2009. Theorizing the Dark Side of the Workplace Spirituality Movement. Journal of Management Inquiry 18: 288-300. [CrossRef]

Lychnell, Lasse. 2017. When work becomes meditation: How managers use work as a tool for personal growth. Journal of Management, Spirituality and Religion 14: 255-75. [CrossRef]

Lynn, Monty L., Michael J. Naughton, and Steve Vander Veen. 2009. Faith at work scale (FWS): Justification, development and Validation of a Measure of Judeo-Christian Religion in the workplace. Journal of Business Ethics 85: 227-43. [CrossRef] 
Mabey, Christopher, Mervyn Conroy, Karen Blakeley, and Sara de Marco. 2017. Having Burned the Straw Man of Christian Spiritual Leadership, what can We Learn from Jesus about Leading Ethically? Journal of Business Ethics 145: 757-69. [CrossRef]

Melé, Domènec, and Joan Fontrodona. 2017. Christian ethics and spirituality in leading business organizations: Editorial introduction. Journal of Business Ethics 145: 671-79. [CrossRef]

Melé, Domènec, and Schlag Martin. 2016. Humanism in Economics and Business. Perspectives of the Catholic Social Tradition. Empresa y Humanismo 19: 181-83.

Moya, Almudena Rodríguez. 2014. Religion in companies: Conflicts and solutions. La religión en la empresa: Problemas y soluciones (Trad.). Estudios Eclesiásticos 89: 817-31.

Pandey, Ashish, Rajen K. Gupta, and A. P. Arora. 2009. Spiritual Climate of Business Organizations and Its Impact on Customers' Experience. Journal of Business Ethics 88: 313-32. [CrossRef]

Pirson, Michael A., and Paul R. Lawrence. 2010. Humanismo en los negocios: ¿hacia un cambio de paradigma? Journal of Business Ethics 93: 553-65. [CrossRef]

Pless, Nicola M., Thomas Maak, and Howard Harris. 2017. Art, ethics and the promotion of human dignity. Journal of Business Ethics 144: 223-32. [CrossRef]

Poole, Eve. 2009. Organizational spirituality: A literature review. Journal of Business Ethics 84: 577-88. [CrossRef]

Robledo, Marco Antonio. 2014. Building an integral metatheory of management. European Management Journal 32: 535-46. [CrossRef]

Roof, Richard A. 2015. The association of individual spirituality on employee engagement: The spirit at work. Journal of Business Ethics 130: 585-99. [CrossRef]

Rothausen, Teresa J. 2017. Integrating leadership development with Ignatian Spirituality: A model for designing a spiritual leader development practice. Journal of Business Ethics 145: 811-29. [CrossRef]

Sandelands, Lloyd E. 2017. The real mystery of positive business: A response from Christian faith. Journal Business Ethics 145: 771-80. [CrossRef]

Silingiene, Violeta, and Sandrita Skeriene. 2016. Links between the Spiritual Intelligence of the Leader and an Organization's Service Quality: A Theoretical Approach. Inzinerine Ekonomika-Engineering Economics 27: 56-65. [CrossRef]

Strecker, Georg. 1998. Makarios. In Diccionario Exegético del Nuevo Testamento. Edited by por Balz Horst and Schneider Gerhard. Salamanca: Sígueme, vol. II, pp. 126-35.

Toro-Jaramillo, Iván-Darío, and Juan Camilo Ramírez Ríos. 2017. La gestión empresarial desde un enfoque humanista. Ponencia presentada en Centro de Desarrollo Empresarial, Medellín, Colombia.

Tourish, Dennis, and Naheed Tourish. 2010. Spirituality at work, and its implications for leadership and followership: A post-structuralist perspective. Leadership 6: 207-24. [CrossRef]

Van Buren, Harry J., and Michelle Greenwood. 2013. The genesis of employment ethics. Journal Business Ethics 117: 707-19. [CrossRef]

Vasconcelos, Anselmo Ferreira. 2009. Intuition, prayer, and managerial decision-making processes: A religion-based framework. Management Decision 47: 930-49. [CrossRef]

Vila Porras, Carolina. 2016. Ser Cristiano Hoy: Propuesta Humanizadora en Mt 5, 3-10. Master's thesis, Universidad Pontificia Bolivariana, Medellín, Colombia.

Wahid, Nur Kamariah Abdul, and Norizah Mohd Mustamil. 2017. Ways to maximize the triple bottom line of the telecommunication industry in Malaysia the potentials of spiritual well-being through spiritual leadership. Journal of Organizational Change Management 30: 263-80. [CrossRef]

Wani, Mudasir Ahmad, and Suraiya Jabin. 2018. Big data: Issues, challenges, and techniques in business intelligence. Advances in Intelligent Systems and Computing 654: 613-28.

Weinberg, Frankie J., and William B. Locander. 2014. Advancing workplace spiritual development: A dyadic mentoring approach. Leadership Quarterly 25: 391-408. [CrossRef]

Yazdani, Naveed, and Hasan S. Murad. 2015. Toward an ethical theory of organizing. Journal of Business Ethics 127: 399-417. [CrossRef]

(C) 2020 by the authors. Licensee MDPI, Basel, Switzerland. This article is an open access article distributed under the terms and conditions of the Creative Commons Attribution (CC BY) license (http://creativecommons.org/licenses/by/4.0/). 